\title{
The Institutional Foundation of the Emergence of Subnational Political Dynasties in Indonesia
}

\author{
Yoes C. Kenawas \\ Department of Political Science \\ Northwestern University \\ Evanston, IL \\ yoes.kenawas@northwestern.edu
}

\begin{abstract}
Decentralization and democratization at the subnational level are two main policies to avoid another centralization of power in the hands of a small number of elites in Jakarta. Instead of solving the problem of concentration of power, the introduction of decentralization and democratization at the subnational level allows some local strongmen to monopolize power at the subnational level through the formation of political dynasties. Why has this contradictory result occurred? The paper argues that the interaction between macrolevel institutional stability and micro-level continuous institutional transformations creates an avenue for power monopolization by a small number of elites at the subnational level. By applying Taylor C. Boas' composite-standard model of path dependence, the paper aims to show that the institutional development not only precedes the rise of subnational political dynasties but also enables such political force to be an enduring feature of Indonesia's political landscape for years to come. Additionally, by using the composite-standard model, the paper aims to capture the complexity and the dynamics of the power struggle between the competing political actors-both at the national and subnational levels - to change or to maintain the existing institutions. This paper supplements some previous studies on the emergence of political dynasties in Indonesia with a more detailed discussion on the institutional aspects that allows such dynasties to exist and to persist. This paper employs secondary data from various sources, including news archives and the Constitutional Court's proceedings to support its claim.
\end{abstract}

Keywords-decentralization; democratization; political dynasties; historical institutionalism; Indonesia

\section{INTRODUCTION}

Soon after the fall of Suharto in 1998, Indonesian reformist leaders designed two policies to avoid another centralization of power in the hands of a small number of elites. The two policies are decentralization of the structure of government and democratization at the subnational levels. Almost two decades after the collapse of the New Order, however, Indonesia is witnessing monopolization of power by the subnational elites, a situation which is contradictory to the initial objective of decentralization and democratization at the subnational levels. Why has this contradictory result occurred? This paper argues that the interaction between the macro-level institutional stability and gradual transformation at the micro-level institutions creates an avenue for monopolization of power by a small number of subnational elites. ${ }^{1}$ This monopolization of power is an unintended consequence of decentralization and democratization in post-New Order Indonesia ${ }^{2}$ and is illustrated by the emergence of local political dynasties at the subnational levels in several provinces and districts across the archipelago [3].

Macro-level institution refers to the decentralized structure of government and the devolved authority to elect subnational leaders, while micro-level institution points to the rules and procedures of local executive election. ${ }^{3}$ This paper, however, focuses more on the latter and treats the former as the background that helps to explain changes in the subnational electoral regime. The primary reason for focusing on the micro-level institution is that the rules and procedures to elect subnational executive leaders have been the most contested institution in the post-critical-juncture period. Consequently, this institution has changed several times and is still being modified to suit the needs of political actors, particularly the national elites who have been disempowered by the decentralization regime. Furthermore, by focusing on the gradual changes of subnational electoral regimes, this paper explains not only the gradual transformation at the micro-level institution but also feedback mechanisms and increasing returns [4] for explaining institutional stability at the macrolevel institutions; distributional effects of institutions and asymmetric power between competing actors [5]; and

\footnotetext{
${ }^{1}$ This paper utilizes Streeck and Thelen's definition of institutions. They treat institutions as regimes, defined as "a set of rules stipulating expected behavior and 'ruling out' behavior deemed to be undesirable" [1]. Furthermore, they argue "A regime is legitimate in the sense and to the extent that the expectations it represents are enforced by the society in which it is embedded" [1]. Defining institutions as a regime has several merits, such as acknowledging potential gaps between the rules and the implementation that can lead to actors' strategic action, thus helping the analyst to identify the source of gradual change; and defining who are the rule taker and rule maker and charting the continuous interaction between the two [1]. Additionally, this paper focusses on formal institutions.

2 This paper supports the argument made by Hadiz [2] regarding how institutional reforms - particularly decentralization and democratization-in Indonesia have caused "localization of power," wherein the "already dominant forces might "further their control or weaken their opponents in broad struggles over social, political, and economic ascendancy"” [2, p.10].

3 Hereinafter, the decentralized structure of government and the devolved authority to elect subnational leader will be used interchangeably with the decentralization regime or the macro-institutions. Additionally, the rules or procedures of local executive election will be used interchangeably with the subnational electoral regime and the micro-institution. Local executive leader refers to governor and mayor/district-head.
} 
reproduction of power as an effect of institutional arrangements at the macro and micro levels [6]. ${ }^{4}$

Thus, this paper aims to highlight the other analytic components of the path-dependent explanation: structural persistence (institutional reproduction), reactive sequence, and outcome of a path-dependent process [7]..$^{5}$ To serve this purpose, the paper adopts Taylor C. Boas' composite-standard model of path dependence with a minor modification [8]. The paper contends that the modified version of Boas' standardcomposite model can capture the complexity and dynamics of interaction between major and minor-level institutions, as well as the power struggle between competing actors - national visà-vis subnational elites - to change or to maintain the existing institutions as well as the outcome of the power struggle. Furthermore, this paper demonstrates that macro-level institutions may persist and be self-reinforcing, but the "operational" or the micro-level institutions may gradually change over time. ${ }^{6}$ The gradual changes of the microinstitutions depend on the position of the competing actors: for the national elites, the viable strategy is through layering; but for the subnational elites, institutional drift is more preferable. ${ }^{7}$

This paper is structured as follows; the first part discusses the modification to Boas' composite-standard model of path dependence. The model serves as a framework for explaining the unintended outcome of Indonesia's decentralization regime. The second part focusses on the application of the model to the empirical case. The final part presents the conclusion of this paper.

\section{Composite-Standard Model of PATH DePENDENCE}

This paper highlights two aspects of Boas'(2007) composite-standard model of path dependence before proceeding with the empirical analysis. First, the model is an instrumental tool for explaining continuity at the macro-level institutions and changes that occur at the micro-level institutions in the post-critical juncture period. ${ }^{8}$ These two processes are often interrelated: increasing returns (lock-in) at

4 This paper acknowledges two other aspects in the study of historical institutionalism, such as temporality and sequencing. The paper, however, does not provide a special section to discuss these two aspects of historical institutional analysis. Nevertheless, the paper implicitly takes into account the analysis of temporality and sequencing in its analysis.

5 Mahoney [7, pp. 112-116] argues that path-dependent explanations require a "series of sequential stages" and consist of antecedent conditions, critical juncture, structural persistence, reactive sequence, and outcome.

6 This paper acknowledges that decentralization and democratization at the subnational level cover a wide range of minor institutions, such as mechanism for electing local executive leaders, scope of central-regional government authority, and profit-sharing over natural resources exploitation. This paper, however, focusses only on the rules and procedures of subnational executive leaders.

${ }^{7}$ Layering and drift are two modes of gradual institutional change coined by Streeck and Thelen [1] and developed further by Mahoney and Thelen [9]. Layering refers to "the introduction of new rules on top of or alongside existing ones" [9, p.15]. Institutional drift happens when "[A] gap opens up between rules and enforcement" [9, p. 21].

8 This paper concurs with Boas' argument regarding institutional complexity. He says, “...the concept of 'institution' is one that may involve multiple nested layers with varying degrees of complexity" [8, p. 44]. the macro-level institutions may be a necessary prerequisite for gradual changes at the micro-level institutions [8]. Furthermore, this paper argues, gradual changes at the subnational electoral regime reflect the competing political actors' strategy in response to a shifting power-distribution caused by the decentralization regime (i.e., the macro-level institutions) [9, pp. 4-8]. Additionally, as argued by Mahoney and Thelen [9], the micro-level institutional changes are also related to the issue of how the competing actors interpret the rules and how the third party enforces the regulations. Thus, Boas' composite-standard model is useful for presenting a more complete and unified picture of Mahoney's [7] concept of institutional reproduction and reactive sequence.

This paper, however, modifies the model by incorporating increasing returns, layering, and drift-instead of increasing returns, layering, and conversion as suggested by Boas' original model-into a single framework. Incorporating drift instead of conversion is important because drift is more appropriate for describing the strategy employed by the local strongmen as they operate in institutions with strong veto possibilities and a high level of discretion in interpretation, but with the limited capacity of the third party to enforce the rule [9, pp. 18-31].

Second, in this paper, the macro-level institutions refer to 1) the decentralized structure of government; and 2) the democratized local leader selection mechanism. ${ }^{9}$ These institutions consist of micro-level institutions that regulate the more operational aspects of the decentralization regime, such as rules and procedures of local executive leader election, role and scope of authority of provincial and district-level governments, and how subnational governments can generate revenue. ${ }^{10}$ As mentioned earlier, changes in the micro-level institutions do not necessarily transform the macro-level institutions. In fact, the stability of the macro-level institutions is necessary for changes at the micro-level institutions. For example, rules and procedures to elect the local executive leaders (governors, mayors, and district heads) may change over time, but it does not discount the fact that the authority to elect local leaders is no longer monopolized by the political elites in Jakarta as during the Suharto regime. ${ }^{11}$

\section{APPLYING THE MODIFIED COMPOSITE-STANDARD MODEL OF PATH DEPENDENCE}

\section{A. Increasing Returns and Layering}

Soon after the implementation of the decentralization in 2001, the pro-unitary state camp - consisting mostly of national-level elites, including the executive leaders and

9 In this paper, the primary distinction between macro and micro-level institutions is whether or not the particular institutions are explicitly stipulated in the amended version of the 1945 Indonesian Constitution. For example, Article 18 of the Constitution explicitly stipulates that: 1) subnational governments have the authority and autonomy to manage their region; and 2) local executive leaders are elected based on democratic principles.

${ }^{10}$ In the case of Indonesia, based on the country's legal system, the microlevel institutions can be found in law, presidential decree, ministerial decree, and government regulation in lieu of law.

11 This does not mean that the political elites in Jakarta are completely powerless. For example, leaders of political parties at the national level have the power to issue the party endorsement letter. 
political parties' leadership — sought to recentralize the decentralized structure of government and the devolved authority to elect local leaders. The rise of President Megawati Sukarnoputri in 2001 — supported by her ex-military confidants who strongly opposed the idea of decentralization-had strengthened the concern for recentralization $\left[10\right.$, p. 7]. ${ }^{12}$ This camp argued that the decentralization policy had significantly curtailed the national elites' authority to control elites in the regions - both executive and legislative. For example, the 1999 decentralization law bestowed local legislatures with authority to elect governors, mayors, and district heads. The legislative members at the subnational levels, however, used their power for rent-seeking purposes (Hadiz 2011). They elected any candidates who were willing to give them more money, and they ignored the instruction from the national parties' leadership. Thus, the parties' leadership at the national level faced difficulties in ensuring that the local legislature elects the nominee endorsed by the national-level party leadership [11]. ${ }^{13}$

The plan for recentralization, however, never materialized for two reasons. First, the amendment of the 1945 Constitution in 2000 significantly limited any attempt to recentralize the structure of government and the mechanism to elect local executive leaders. The costs - a political bargain with other parties in a multiparty system and pressure from prodemocracy activists - for amending the constitution would have been very expensive for any democratic leader to bear after the critical juncture period ended. ${ }^{14}$

Second, the local elites were adamant in rejecting any centralization attempt by the national elites. They realized that the decentralization policies were critical for serving their political and economic interests in the regions. The subnational elites-through various associations like the Association of Provincial Government (APPSI), the Association of Municipal Government (APEKSI), the Association of District Government (APKASI), and the Association of Local Legislator (ADEKSI) - shaped the national-level discourse by exploiting pro-democracy sentiment: any recentralization attempt must be seen as an effort to regress the democratic progress in post-Suharto Indonesia. ${ }^{15}$ Additionally, the

12 On July 23, 2001, Megawati replaced Abdurrahman Wahid (Habibie's successor who occupied the presidency for 21 months) and became the fourth president of Indonesia. Megawati is the daughter of the first Indonesian president Sukarno. She is a figure with a very strong nationalistic view. During Suharto's presidency, Megawati was one of the icons of the oppositional movement. Megawati, however, has always been a strong proponent of Jakarta-centric policy and very reluctant about the ideas of decentralization, federalism, and giving special autonomy to troubled provinces.

13 Additionally, according to the national elites, this situation had impeded the central government's development strategies and could jeopardize its legitimacy. Furthermore, the pro-unitary camp also argued that the decentralization law had threatened the national unity.

14 This fact supports the argument of scholars like Mahoney [7], Pierson [4], Capoccia and Keleman [12], and Soifer [13] who argue that any future decisions/choices in the post-critical juncture period should consider the institutional products of the critical junctures. As argued in the previous paper, the critical juncture period lasted from mid-1998 (when Suharto stepped down from the presidency) to late-2000 (when the amended version of the 1945 Constitution was adopted).

15 Unsurprisingly, some of the founders of these associations were also the founders of local political dynasties, particularly after they completed their subnational elites also threatened the national elites by reminding the latter of the perils of secessionist movement if they pushed forward for a recentralization policy [14].

At this point, one can observe that the reproduction/positive feedback/lock-in of macro-level institutions was at work. The decentralization regime, supported by the newly-amended Constitution, served to "actively facilitate the organization and empowerment of certain groups [subnational elites] while actively disarticulating and marginalizing others [national elites]" [15]. The pro-democratic and pro-decentralization sentiments at the grassroots level in the early 2000s - in the context of just a few years after the fall of Suharto's authoritarian regime - also contributed to the positive feedback of the macro-institutions. The peculiar coalition between the subnational leaders and pro-democratic movement prevented the national elites from re-engineering the macro-institutions.

Additionally, the threat made by the subnational leaders was one of the crucial factors that prevented the adoption of recentralization policy. This argument is particularly reasonable because from 1998 to the early 2000s, Indonesia experienced three major secessionist movements in Aceh, Papua, and East Timor, and numerous horizontal conflicts at the district level, such as in Ambon (Maluku), Poso (Central Sulawesi), Banyuwangi (East Java), and Sampit (Central Borneo). No Indonesian democratic leader could afford another bloody conflict in the region that might occur if they insisted on recentralizing the structure of government and the subnational electoral regime. More importantly, it highlights the power asymmetries between the national elites vis-à-vis the coalition of regional elites, wherein the latter is stronger than the former. Eventually, in Sulistiyanto and Erb's words, "decentralization is accepted as a new reality in post-Suharto Indonesia" [10].

Within this context, the national elites were able to deploy only layering as their strategy to partially restore their control over the subnational elites. Thus, in 2004 , the national elites introduced the Law 32/2004 on Regional Government. In principle, the new law only modified some operational rules and procedures of the Law No. 22/1999 (micro-level institutions); it did not fundamentally transform the decentralization regime (macro-institutions). Nonetheless, one of the most crucial points of the Law 32/2004 was the introduction of direct local election as a mechanism for electing local executive leaders, replacing the indirect election by local legislatures. The national elites were able to modify the rules and procedures for electing local executive leaders by tapping into negative public sentiment over the behavior of local legislators who exploited their authority to elect local executive leaders for their personal economic interests. The national elites argued that the direct local elections would improve the vertical accountability between the elected executive leaders and the public [11]. The national elites' real motivation, however, was to regain their control over the subnational elites,

second term. They include Syaukani H. R. (the founder of the Syaukani dynasty in Kutai Kartanegara District), Syahrul Yasin Limpo (the founder of the Limpo Dynasty in South Sulawesi Province), and Idham Samawi (the founder of the Samawi dynasty in Bantul District). It is also important to note here that APEKSI-APKASI, ADEKSI, and APPSI are not necessarily friendly to one another. 
because any nominee in the direct local elections would require the authorization of the central party leadership; and in many cases, the hopeful nominees needed to pay some money to the party leadership, both at the national and subnational levels [16].

The introduction of direct local elections, however, has brought some negative consequences. First, instead of improving the vertical accountability (i.e., candidate-voter relationship), direct local elections have exacerbated the practice of money politics. This time, the money politics occurs not between the candidates and the local legislatures, but between candidates and political parties, as well as between candidates and the voters. ${ }^{16}$ The second negative consequence, related to the practice of money politics, is that the overall costs that need to be borne by any candidates who join the direct local elections have increased at an unprecedented level [11]. Candidates realize that the financial costs for running in direct local elections are part of their "investment." How, then, do they recompense this investment? For return on their investment, once they win the election, they involve themselves in rent-seeking behavior. Furthermore, candidates' engagement in rent-seeking activities serve not only to redeem their investment but also to finance their re-election and boost their personal wealth. In other words, the direct local elections have turned into a business model. As in any business model, the actors need to ensure the continuity and expand the scope of their business by opening other branches to maintain, strengthen, and expand their source of income. In this context, building political dynasties has become a viable strategy to maintain, strengthen, and expand the source of income of some local politicians.

\section{B. Increasing Returns and Drift}

As mentioned earlier, some local politicians build political dynasties as a strategy to maintain, strengthen, and expand their source of income. ${ }^{17}$ Buehler [11] argues that there are two types of political dynasty. The first type is a political dynasty that is merely a continuation of an elected official from an incumbent to one of his/her family members. ${ }^{18}$ The second type is a political dynasty that expands the power of the incumbent

\footnotetext{
${ }^{16}$ Two factors have contributed to the pervasiveness of money politics. First, there is no legal mechanism that prevents money politics between candidates and political parties. Second, the local election supervisory board has only limited capacity to monitor the money politics between candidates and voters. The subnational election rules stipulate that the local election management body's and the local election supervisory body's financing depend on the discretion of the local government. Thus, incumbents can easily curtail the effectiveness of the two bodies. Consequently, the candidates are able to exercise a various "menu of manipulations," such as distributing various forms of patronage, mobilizing local civil servants, threatening the voters, and rigging the voting ballots. "Menu of manipulation" is a term coined by Andreas Schedler [17] for describing various tactics deployed by authoritarian leaders for shaping the election result.

17 It is important to note that during Suharto's authoritarian regime, political dynasties at the subnational levels did not exist. Thus, the emergence of political dynasties is closely related to the institutional transformation in the reform era.

18 For example, in 2010 the incumbent Irianto MS Syaifuddin was replaced by his wife Anna Sophana, after he finished his second term as the district head of Indramayu District.
}

by helping his/her family members to occupy other offices at the lower-level of government. The second type is usually practiced by a governor who helps his/her family members to become a district head in the province ruled by the governor. ${ }^{19}$ Furthermore, in this type of dynasty, the family members who become district heads not only strengthen the power of the governor but also are prepared to take over the governorship when the incumbent reaches his/her term limit.

Both types of political dynasty are a political response to the legal limitation set by both macro- and micro-level institutions: the term limit. The Constitution and the Law No. 32/2004 on Regional Government stipulate that an incumbent in the executive office can serve for only another five years in the same office throughout his/her lifetime. The macro- and micro-level institutions, however, do not forbid family members of the incumbent from running in an election to replace the latter. In this context, building a political dynasty is a viable strategy for the incumbent to maintain his/her power as well as his/her source of income. In 2013, the data from the Indonesian Ministry of Home Affairs showed that at least 60 political dynasties have emerged across the archipelago since the introduction of direct local elections in 2005 [18].

What does the emergence of political dynasties convey regarding institutional changes? One way to interpret the emergence of the dynasties is institutional drift exercised by the subnational politicians. The local politicians operate in a setting wherein changing both macro- and micro-level institutions is not permissible. The defenders of the Law $32 / 2004$ have strong veto possibilities. The veto players (the national elites) have strong political support from the public (recall that the public supported the direct local election as a mechanism to improve vertical accountability), and there are many institutional veto points, including the constitutional veto points. The Law 32/2004, however, provides ample room for dynastic politicians to maneuver. Family members of the incumbent are allowed to run for office. Additionally, as mentioned earlier, the capacity of the electoral supervisory body at the local level has been heavily curtailed by the fact that its funding depends on the discretion of the incumbent. Consequently, the implementation of rules that prohibit the practice of money politics and distribution of other kinds of patronage has never been effective. Kenawas [19] found that almost all elections joined by dynastic politicians have been disputed at the Constitutional Court (MK) for various allegations related to money politics, mobilization of bureaucracy, and distribution of other forms of patronage.

More importantly, however, these dynastic politicians do not aspire to modify the existing institutional arrangements. In fact, they rely on the existing institutional arrangements to reproduce their power. Thus, when in 2014 the Yudhoyono administration introduced an anti-dynastic clause in the Government Regulation in Lieu of Law 1/2014 (due to enormous pressure from democratic activists), some dynastic politicians contested the Government Regulation in the

19 For example, in 2010 then Governor of Jambi Zulkifli Nurdin helped his son Zumi Zola to become the district head of Tanjung Jabung Timur, a district within the jurisdiction of the governor. 
Constitutional Court. ${ }^{20}$ They argued that the anti-dynastic clause was discriminatory and violated the democratic principles of the Constitution [20]. Eventually, the Constitutional Court abolished the anti-dynastic clause; the Court concurred with the argumentation of the dynastic politicians that the clause was discriminatory and violated democratic principles as stated in the Constitution. This event suggests that dynastic politicians can skillfully maneuver around macro- and micro-level institutions.

Therefore, using Mahoney and Thelen's [9, pp. 22-29], dynastic politicians fall into the parasitic symbionts category. Furthermore, in regard to macro-level institutions, as parasitic symbionts, dynastic politicians flourish in "environments characterized by strong veto possibilities and high enforcement discretion" [9, p. 28]. This situation makes them a natural ally of the defenders of the status quo at macro-level institutions (i.e., the Constitutional Court) and a natural opposition to the insurrectionary (i.e., the national-level elites)" $\left[9\right.$, p. 31]. ${ }^{21}$

Finally, since the anti-dynastic clause is no longer in place, the dynastic politicians can continue their business as usual. They can constantly reproduce their power by relying on the existing institutional arrangements. This is a perfect example of power begets power [21]. In the long run, however, the emergence of political dynasties could jeopardize the legitimacy and credibility of decentralization and democratization at the subnational levels

\section{CONCLUSION}

The emergence of local political dynasties is puzzling because one of the initial objectives of the decentralization regime was to avoid monopolization of power by a small number of elites; yet, local strongmen in some provinces and districts are able to monopolize power to serve their private and family interests. This paper shows that the formation of political dynasties is a strategy employed by parasitic symbionts - i.e., the dynastic politicians - to adapt to the new institutional environment in post-Suharto Indonesia. They achieve their success in a setting wherein organizational capacity, and the resources of the rules of enforcement bodies are limited. Their success in building political dynasties, however, is contradictory to the "spirit" of the decentralization regime.

This paper also shows that Boas' composite-standard model of path dependence is useful to supplement Mahoney's model of path dependence analysis. The model is useful to show the complexity of institutional analysis. Boas' model can capture various aspects in the study of historical institutionalism, including institutional stability; reactive sequence and gradual changes; and power asymmetries as well as power reproduction. More specifically, Boas' model can

\footnotetext{
${ }^{20}$ One can interpret Yudhoyono's move as a layering strategy employed by national elites.

21 In this case, the coalition between dynastic politicians and the Constitutional Court is atypical. Mahoney and Thelen say that when "[T]he substantive goals of symbionts [the dynastic politicians] are frequently at odds with those of current institutional supporters [the Constitutional Court], strange coalitions can emerge" [9, p. 31].
}

show that stability of an institution may cause changes in other institutions, primarily because the related actors adapt to distributional effects of the institutions. Overall, Boas' composite-standard model can be a viable alternative for analysts who seek to present a complete picture of historical institutional analysis.

\section{REFERENCES}

[1] W. Streeck and K. Thelen, "Introduction: Institutional Change in Advanced Political Economies," in Beyond Continuity: Institutional Change in Advanced Political Economies, W. Streeck and K. Thelen, Eds. New York: Oxford University Press, 2005, pp. 12-13.

[2] V. Hadiz, Localising Power in Post-Authoritarian Indonesia: A Southeast-Asia Perspective. Singapore: ISEAS Publishing, 2011.

[3] M. Buehler and P. Tan, "Party-candidate relationships in Indonesian local politics: A case study of the 2005 regional elections in Gowa, South Sulawesi Province," Indonesia, no. 84, pp. 41-69, Oct. 2007.

[4] P. Pierson, Politics in Time: History, Institutions, and Social Analysis, New Jersey: Princeton University Press, 2004.

[5] J. Knight, Institutions and Social Conflict, New York: Cambridge University Press, 1992.

[6] P. Pierson, "Power and Path Dependence," in Advances in Comparative-Historical Analysis, J. Mahoney and K. Thelen, New York: Cambridge University Press, 2015, pp. 123-146.

[7] J. Mahoney, "Path-Dependent Explanations of Regime Change: Central America in Comparative Perspective," Studies in Comparative International Development, vol. 36, no. 1, pp. 111$141,2001$.

[8] T. C. Boas, "Conceptualizing Continuity and Change: The Composite-Standard Model of Path Dependence," Journal of Theoretical Politics, vol. 19, no. 1, pp. 33-54, 2007.

[9] J. Mahoney and K. Thelen, "A Theory of Gradual Institutional Change," in Explaining Institutional Change: Ambiguity, Agency, and Power, by J. Mahoney and K. Thelen, Eds. New York: Cambridge University Press, 2010, pp. 1-37.

[10] P. Sulistiyanto, and M. Erb, "Introduction," in Regionalism in Post-Suharto Indonesia, M. Erb, P. Sulistiyanto and C. Fuacher, New York: Routledge Courzon, 2005, pp. 1-18.

[11] M. Buehler, "Decentralization and Local Democracy in Indonesia: the Marginalization of the Public Sphere," in Problems of Democratisation in Indonesia: Elections, Institutions and Society, M. Mietzner and E. Aspinall, Eds. Singapore: ISEAS Publishing, 2010, pp. 267-285.

[12] G. Capoccia and R. D. Keleman, "The Study of Critical Junctures: Theory, Narrative, and Counterfactuals in Historical Institutionalism," World Politics, vol. 59, no. 3, pp. 341-369, 2007.

[13] H. D. Soifer, "The Causal Logic of Critical Junctures," Comparative Political Studies, vol. 45, no. 12, pp. 1572-1597, 2012.

[14] Surabaya Post. (2001, May 22). Districts to Treat Regional Autonomy Like 'Independence Struggle'.

[15] K. Thelen, "Historical Institutionalism in Comparative Politics," Annual Review of Political Science, vol. 2, pp. 369-404, 1999.

[16] A. Azra. (2016, Mar 16). Political Dowry, the Politics of Dowry. Kompas.
http://nasional.kompas.com/read/2016/03/16/10594231/Mahar.P olitik.Politik.Mahar?page=all. 
[17] A. Schedler, "The Menu of Manipulation," Journal of Democracy, vol. 13 no. 2, pp. 36-50, 2002.

[18] Kompas. (2013, Oct. 18). 60 Incumbents Are Members of Political Dynasties. Kompas. Available: http://nasional.kompas.com/read/2013/10/18/1850579/60.Orang. yang.Terlibat.Politik.Dinasti
[19] Y. C. Kenawas, "The Rise of Political Dynasties in a Democratic Society," presented at the 2014 Arryman Fellow's Symposium, IL, 2015.

[20] Tribun Timur. (2015, Jun. 29). TYL is Waiting for the Constitutional Court Decision."

[21] E. Dal Bó, P. Dal Bó, and J. Snyder, "Political Dynasties," The Review of Economic Studies, vol. 76, no. 1, pp. 115-142, 2009. 